\title{
QUATERNARY MARINE MOLLUSKS IN TIERRA DEL FUEGO: INSIGHTS FROM INTEGRATED TAPHONOMIC AND PALEOECOLOGIC ANALYSIS OF SHELL ASSEMBLAGES IN RAISED DEPOSITS
}

\author{
MOLUSCOS MARINOS CUATERNARIOS EN TIERRA DEL FUEGO: UNA \\ VISIÓN INTEGRANDO EL ANÁLISIS TAFONÓMICO Y PALEOECOLÓGICO \\ DE LOS ENSAMBLES DE CONCHILLAS EN DEPÓSITOS ELEVADOS
}

Sandra Gordillo ${ }^{1,2}$

"Everything in this southern continent has been effected on a grand scale: the land, from the Rio Plata to Tierra del Fuego, a distance of 1200 miles, has been raised (..), within the period of the now existing sea-shells. The old and weathered shells left on the surface of the upraised plain still partially retain their colours." January 9th, 1834, The Vogage of the Beagle, Charles Darwin.

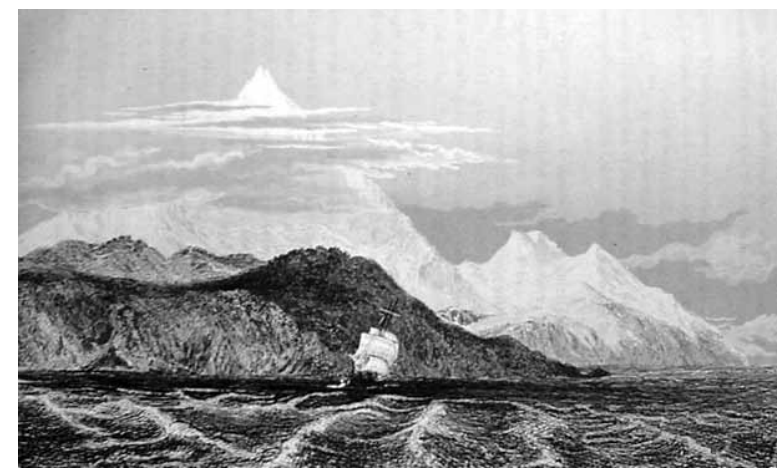

H.M.S. Beagle in Murray Narrow, Beagle Channel; from a watercolour by Conrad Martens.

1 Centro de Investigaciones en Ciencias de la Tierra, Consejo Nacional de Investigaciones Científicas y Técnicas (CICTERRA, CONICET).

2 Centro de Investigaciones Paleobiológicas (CIPAL), Facultad de Ciencias Exactas, Físicas y Naturales, Universidad Nacional de Córdoba. Av. Vélez Sársfield 299 X5000JJC Córdoba, Argentina.sgordillo@efn.uncor.edu 


\begin{abstract}
During the Quaternary the southern tip of South America was affected by several glaciations which might have excluded much of the benthic marine fauna inhabiting this region, with the consequent interruption of the connection between the Atlantic and the Pacific Oceans. In that context, fossil marine mollusks recovered from interglacial (Pleistocene) and postglacial (Holocene) Quaternary deposits of Tierra del Fuego, provide a key for the reconstruction of paleocommunities and the evaluation of changes in faunal composition over time. Paleontological database was compiled from previous works, showing a diverse fauna, which includes 91 different species (61.5\% gastropods; 31.9\% bivalves and 6.6\% chitons). Quaternary time-averaged mollusk assemblages from Tierra del Fuego give a very good picture of the overall coastal benthic biodiversity patterns in the region. The composition of mollusk species showed remarkable similarities with present- day fauna, which reinforces the hypothesis that climatic conditions have maintained without significant changes since at least the Middle Pleistocene. However, taphonomic and paleoecological analysis of shell assemblages shows the existence of different shallow benthic communities, which represent spatial and temporal variations among regions and sites.
\end{abstract}

Key words: mollusks, taphonomy, paleoecology, Quaternary, Tierra del Fuego.

\title{
RESUMEN
}

Durante el Cuaternario, el extremo sur de Sudamérica fue afectado por varias glaciaciones que habrían excluido gran parte de la fauna marina bentónica que habitaba en la región, interrumpiendo la conexión entre los océanos Atlántico y Pacífico. En ese contexto, los moluscos marinos fósiles recuperados de depósitos interglaciales (Pleistoceno) y postglaciares (Holoceno) del Cuaternario de Tierra del Fuego, son un indicio para la reconstrucción de paleocomunidades y la evaluación de cambios en la composición faunística a través del tiempo. La base de datos paleontológica fue compilada de trabajos previos, y mostró una fauna diversa, que incluye 91 especies diferentes (61,5\% gastrópodos; 31,9\% bivalvos y 6,6\% quitones). Los ensambles de moluscos del Cuaternario de Tierra del Fuego representan un lapso de tiempo (o promedio temporal), y dan un buen panorama de los patrones de la biodiversidad bentónica del área costera en la región. La composición de las especies de moluscos mostró una gran similitud con la fauna actual, lo que refuerza la hipótesis de condiciones climáticas sin cambios significativos al menos desde el Pleistoceno Medio. Sin embargo, el análisis tafonómico y paleoecológico de las asociaciones de moluscos señala la existencia de diferentes comunidades bentónicas de aguas someras, que representan variaciones espaciales y temporales entre las distintas regiones y sitios.

Palabras clave: moluscos, tafonomía, paleoecología, Cuaternario, Tierra del Fuego.

\section{INTRODUCTION}

Shells of mollusks are the most common remains in Quaternary marine deposits along the southern (Beagle Channel), eastern (Atlantic Ocean) and western (Strait of Magellan) coasts of Tierra del Fuego (Fig. 1). They are well preserved, and despite the taphonomic bias (i.e., the loss of soft body taxa, post burial processes), Quaternary mollusk assemblages retain useful information about the life habits and habitats of the marine benthos from which they are derived (Aitken 1990).
A death assemblage is not biologically equivalent to a census of a living community, but sums dead-shell input (minus shell destruction) over some longer period, permitting accrual of a time-averaged species richness (Kidwell 2002). Kidwell (2001) examined the preservation of species abundance in marine death assemblages and noted that species that are dominant in a single live census also dominate the local death assemblage, and species that are rare or unsampled alive are also rare in death assemblages. The fossil record, therefore, largely portrays the modern faunas from which it is derived. 


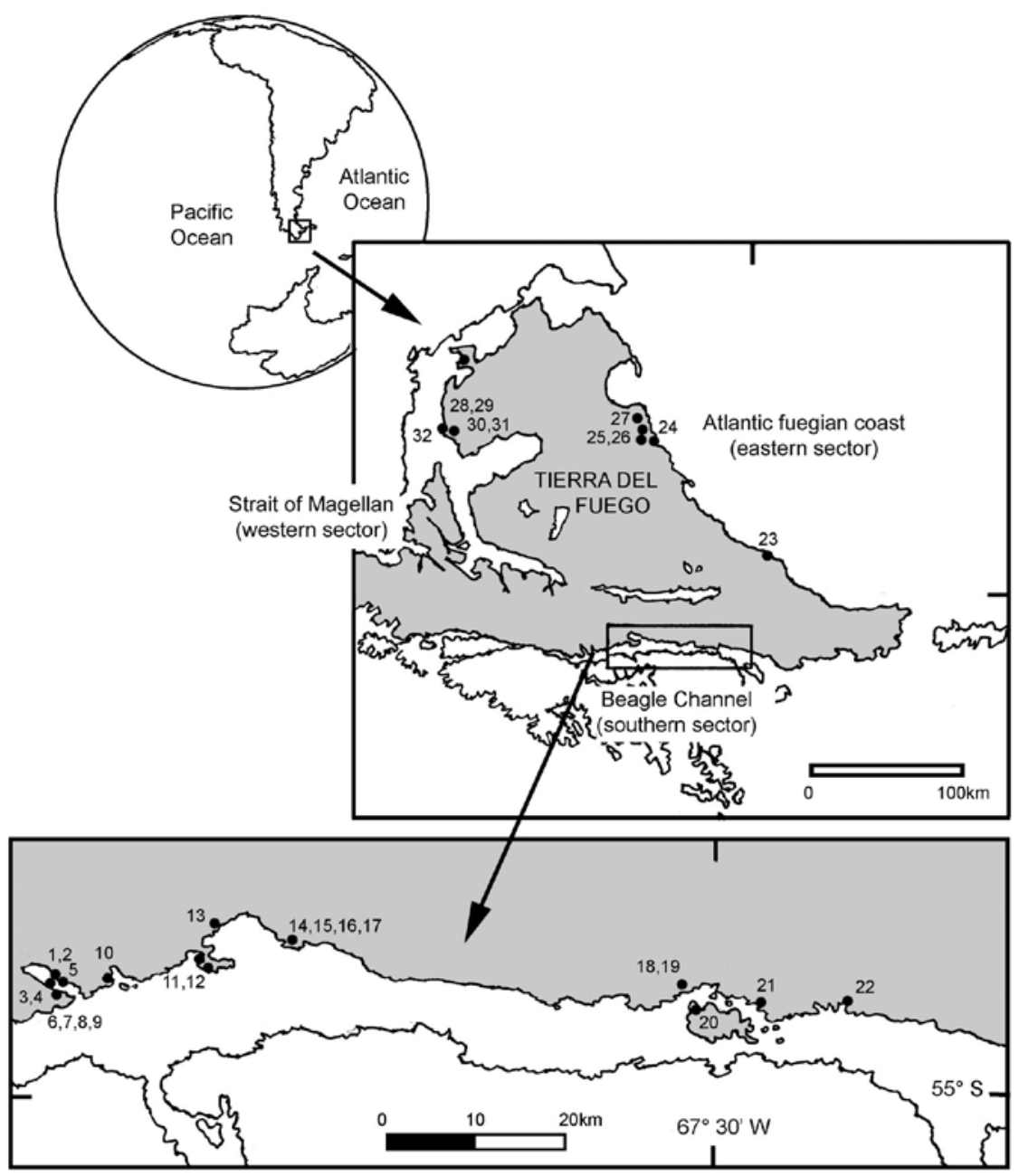

Fig. 1. Map of Tierra del Fuego showing localities considered in this work.

During the Quaternary, the southern tip of South America was affected by several glaciations which might have excluded much of the benthic marine fauna inhabiting this region, with the consequent interruption of the connection between the Atlantic and the Pacific Oceans. In that context, fossil marine mollusks recovered from interglacial (Pleistocene) and postglacial (Holocene) Quaternary deposits of Tierra del Fuego, provide a key for the reconstruction of paleocommunities and the evaluation of changes in faunal composition over time.

An early mention of fossil mollusks in southern South America was given by Charles Darwin in 1833 during his visit to this region on board the HMS Beagle. But the first report of Quaternary fossil mollusks from Tierra del Fuego was made by R. Hägg (in Halle 1910), who provided a short list of taxa collected at Isla Gable on the Beagle Channel. Then, Feruglio (1950) also listed some taxa from Río Grande, on the Atlantic coast. Other mentions from the Beagle Channel appeared in Porter et al. (1984) and Rabassa et al. (1986). Later, several works centered on Quaternary mollusks along the Beagle Channel include preliminary taxonomic lists (Gordillo 1993, Gordillo et al. 2005), taphonomic analysis based on bivalves (Gordillo 1992) ${ }^{1}$ and chitons (Gordillo 2007), paleoecological reconstructions (Gordillo 1991, 1999) and

1 Gordillo, S. 1992. Tafonomía y paleoecología de moluscos bivalvos del Holoceno del Canal Beagle, Tierra del Fuego. Doctoral thesis, Universidad Nacional de Córdoba, 286 pp. 
paleoenvironmental interpretations (Gordillo et al. 2005, Candel et al. 2009, Rabassa et al. 2009²). Similar studies focused on mollusks of Tierra del Fuego were recently performed on fossil assemblages from northeastern Atlantic coast (Gordillo 2006, Gordillo \& Isla 20083), and the Strait of Magellan (Cárdenas \& Gordillo 2009).

The aim of this paper is to summarize and to compare mollusk assemblages from the western, southern and eastern coasts of Tierra del Fuego, emphasizing their paleoenvironmental implications.

\section{INTERGLACIAL AND POSTGLACIAL MARINE DEPOSITS IN TIERRA DEL FUEGO}

In southern Tierra del Fuego, the Postglacial marine transgression is represented by several discontinuous raised terraces along the northern Beagle Channel coast. Four informal terrace units have been recognized: Ancient Low Terrace, High Terrace, Middle Terrace and Recent Low Terrace, deposited ca. 8000, 6000, 5000-3000 and after 3000 yr B.P., respectively (Gordillo 1993). Similarly, in western Tierra del Fuego, Brambati et al. (1998) also described four orders of marine terraces: I, II, III and IV, which were deposited at different ages during the Postglacial period. In southern as much as western Tierra del Fuego, located at the active seismotectonic setting of the Fuegian Andes (Scotia Plate Domain), altitudinal differences among raised beaches appear related to tectonic uplift and/or isostatic recovery following deglaciation (Brambati et al. 1998, Rabassa et al. 2000, Bujalesky et al. 2004). In relation to marine deposits corresponding to the Pleistocene marine transgressions, it seems they have not been preserved in both these regions due to the intense erosive effect of the Last Glaciation (Rabassa et al. 2000). However,

2 Rabassa, J., A. Coronato, S. Gordillo, M.S. Candel \& M.A. Martínez 2009. Paleoambientes litorales durante el inicio de la transgresión marina holocena en Bahía Lapataia, Canal Beagle, Parque Nacional Tierra del Fuego, Argentina. Revista de la Asociación Geológica Argentina. In press.

3 Gordillo, S. \& F. Isla 2008. Quaternary mollusk assemblages from the northern Atlantic coast of Tierra del Fuego (southern South America): taphonomy and paleoecology. 4th RCANS (Regional Committee for Atlantic Neogene Stratigraphy) Congress. Buenos Aires, Argentina. Resúmenes: p. 28. scanty shells recovered from till (Gordillo 1990a $a^{4}$ ), and a very rich marine unit recently discovered in Navarino Island, which is still under study (Rabassa et al. 2008), indicate that the Beagle Channel and the Magellan Strait were occupied by seawater at least once before the Last Glaciation.

Finally, the eastern Tierra del Fuego coast includes a terrace system with different sea level highstands from the Middle Pleistocene to the Holocene (Bujalesky et al. 2001). This region, located away from the Andes foldbelt, lies on a more stable setting; however, tectonic activity cannot be entirely excluded from stable continental margins like the Patagonian Atlantic coast (Schellmann \& Radtke 2003), and regional seal level correlations among these sites should be taken with caution.

\section{MATERIAL AND METHODS}

Paleontological database is compiled from previous works mainly focused on Tierra del Fuego (Gordillo 1992¹, Gordillo 1999, Gordillo et al. 2005, Gordillo 2006, Cárdenas \& Gordillo 2009, Gordillo \& Isla $2008^{3}$, and references therein). These specimens are deposited in the Centro de Investigaciones Paleobiológicas (CIPAL), Universidad Nacional de Córdoba, Argentina.

Mollusk assemblages were collected from localities previously studied and dated by different authors (See references in Table 1). However, a radiocarbon calibration, and a radiocarbon reservoir correction are necessary in order to be more realistic, and to compare terrestrial and marine samples. In Tierra del Fuego, local reservoir values were previously calculated by different authors: at the Strait of Magellan, a reservoir effect of 380 \pm 100 yr (Angiolini \& Fernández 1984), and, in the Beagle Channel, a reservoir effect of $630 \pm 70$ yr (Albero et al. 1987). In this work, radiocarbon dates of the different studied sites were calibrated using Radiocarbon Calibration Program (Stuiver et al. 1993). As a first approximation to correct these dates for marine reservoir effect, a marine calibration dataset (Reimer \& Reimer 2000), which incorporates a time-dependent global ocean reservoir correction of about 400 years, and a difference $\Delta R$ of $221 \pm 40$

4 Gordillo S. 1990a. Presencia de Limopsis marionensis Smith, 1885 (Mollusca: Bivalvia) en el Pleistoceno Superior de Tierra del Fuego. In: Actas XI Congreso Geológico Argentino 2: 219-221. San Juan, Argentina. 
TABLE 1. Localities and chronological control performed by different authors. See geographical location in Fig. 1.

\begin{tabular}{|c|c|c|c|c|c|c|c|}
\hline $\begin{array}{c}\text { Number } \\
\text { (Fig. 1) }\end{array}$ & Localities & $\mathrm{m}$ a.s.l. & Laboratory no ${ }^{a}$ & 14C age & $\begin{array}{l}\text { Minimum } \\
2 \sigma \text { B.P. }\end{array}$ & $\begin{array}{c}\text { Maximum } \\
2 \sigma \text { B.P. }\end{array}$ & $\begin{array}{l}\text { Mean } \\
\text { value }\end{array}$ \\
\hline 1 & Lago Roca (lower level) & 4.0 & NZ-7730 & $7518+/-58(7)$ & 7622 & 7915 & 7769 \\
\hline 2 & Lago Roca (upper level) & 6.4 & AC-1060 & $5920+/-90(2)$ & 5892 & 6295 & 6094 \\
\hline 3 & Río Ovando & 3.0 & SI-6735 & $4425+/-55(2)$ & 4092 & 4480 & 4286 \\
\hline 4 & Río Ovando & 2.5 & Pta-7573 & $4160+/-45(9)$ & 3750 & 4111 & 3931 \\
\hline 5 & Alakush & 5.0 & AC-0937 & $4440+/-120(1)$ & 4138 & 4489 & 4314 \\
\hline 6 & Lapataia & 1.6 & SI-6737 & $8240+/-60(2)$ & 8332 & 8644 & 8488 \\
\hline 7 & Lapataia (Baliza) & $-1,50$ & AA $74046^{*}$ & $2844+/-34$ (13) & 2145 & 2451 & 2298 \\
\hline 8 & Lapataia (Aserradero I) & 0,50 & AA74074* & $8094+/-43(13)$ & 8187 & 8451 & 8319 \\
\hline 9 & Lapataia (Aserradero II) & 0,50 & AA74048* & $8167+/-43(13)$ & 8300 & 8541 & 8421 \\
\hline 10 & Ensenada & 2.2 & Pa-1012 & $2120+/-45(6)$ & 1305 & 1584 & 1445 \\
\hline 11 & Bahía Golondrina & 2.0 & AA $62801^{*}$ & $6276+/-41(12)$ & 6337 & 6626 & 6482 \\
\hline 12 & Península Ushuaia & 10 & AECV-877 Cc & $5460+/-110(3)$ & 5329 & 5862 & 5596 \\
\hline 13 & Ushuaia & 8.0 & AECV-876 Cc & $5160+/-130(3)$ & 4895 & 5568 & 5232 \\
\hline 14 & Playa Larga I & 8.0 & Pa-1018 & $5615+/-120(6)$ & 5485 & 6059 & 5772 \\
\hline 15 & Playa Large II & 5.2 & $\mathrm{~Pa}-1015$ & $4335+/-60(6)$ & 3965 & 4387 & 4176 \\
\hline 16 & Playa Larga III & 3.8 & Pa-1016 & $3095+/-60(6)$ & 2390 & 2778 & 2584 \\
\hline 17 & Playa Larga IV & 1.6 & Pa-1017 & $405+/-55(6)$ & -5 & -1 & $* * *$ \\
\hline 18 & Bahía Brown II & 4.0 & Pa-1010 & $2970+/-70(6)$ & 2302 & 2697 & 2500 \\
\hline 19 & Bahía Brown III & 2.6 & $\mathrm{~Pa}-1011$ & $985+/-135(6)$ & 90 & 631 & 361 \\
\hline 20 & Isla Gable, NW & 5.0 & AECV-648 Cc & $4790+/-100(4)$ & 4442 & 5051 & 4747 \\
\hline 21 & Harberton & 2.3 & Pa-1009 & $2770+/-50(6)$ & 2038 & 2347 & 2193 \\
\hline 22 & Río Varela & 3.0 & Pta-7581 & $6240+/-70(9)$ & 6277 & 6626 & 6452 \\
\hline 23 & Río Chico site & 7.0 & LP-1011 & $4620+/-70(10)$ & 4365 & 4802 & 4584 \\
\hline 24 & San Pablo site & 3.0 & AECV-880 Cc & $470+/-90(5)$ & -5 & 148 & 72 \\
\hline 28 & Punta Zeger (upper level) & 5,0 & & $6000-5000(8)$ & & & \\
\hline 29 & Punta Zeger (lower level) & 2,0 & & $5000-4000(8)$ & & & \\
\hline 30 & Punta Palo (upper level) & 2,3 & & $5000-4000(8)$ & & & \\
\hline 31 & Punta Palo (lower level) & 1,2 & & $2000-1000(8)$ & & & \\
\hline \multirow[t]{2}{*}{32} & Bahía Porvenir & 2.0 & & $5000-4000(8)$ & & & \\
\hline & & & & U series method & & & \\
\hline 25 & Laguna Arcillosa & 29 & C6334-U622** & ¿600,000/400,000? (11) & & & \\
\hline 26 & Las Vueltas & 25 & C6473-632R** & $¿<300,000 ?(11)$ & & & \\
\hline 27 & La Sara & 14 & C6472-U631** & $82,000+/-2,5(11)$ & & & \\
\hline
\end{tabular}

a: AA: NSF-Arizona AMS Laboratory (University of Arizona); AC: Instituto de Geocronología Isotópica (INGEIS, Argentina); AECV: Alberta Environmental Center of Vegreville (Canada); LP: Laboratorio de Tritio y Radiocarbono (LATYR, Argentina) NZ: DSIR, Institute of Nuclear Sciences, New Zealand; Pa: Paris VI University (France); Pta: Quaternary Dating Research Unit (Pretoria, South Africa); SI: Smithsonian Environmental Research Center (USA).

Source: (1) Figuerero \& Mengoni Goñalons, 19865; (2) Rabassa et al., 1986; (3) Gordillo, 1990b6; (4) Gordillo, 1991; (5) Gordillo, 1992; (6) Gordillo et al., 1992; (7) Gordillo et al., 19937; (8) Brambatti et al. 1998; (9) Coronato et al. (1999); ; (10) Isla \& Bujalesky (2000); (11) Bujalesky et al. (2001); (12) Gordillo et al. 2008; (13) Rabassa et al. 2009. (*) AMS analysis. (**) U series analysis in the Quaternary Dating Research Unit in Pretoria, South Africa. (***) Beyond the age range of calibration curve used.

5 Figuerero, M.J., Mengoni, G.L. 1986. Excavaciones arqueológicas en la Isla El Salmón, Parque Nacional de Tierra del Fuego. PREP, Informes de Investigación 4: 1-95.

6 Gordillo, S. 1990b. Malacofauna de los niveles marinos holocenos de la Península Ushuaia y alrededores (Canal Beagle, Argentina). In Reunión de campo de Geología del Cuaternario, 3: 24-25. Bahía Blanca, Argentina.
7 Gordillo, S. 1993. Las terrazas marinas holocenas de la región del Beagle (Tierra del Fuego) y su fauna asociada. In Actas XII Congreso Geológico Argentino 6: 34-39. Mendoza.

8 Coronato, A., J. Rabassa, A. Borromei, M. Quattrochio \& G. Bujalesky 1999. Nuevos datos sobre el nivel relativo del mar durante el Holoceno en el Canal Beagle, Tierra del Fuego, Argentina. In Congreso Argentino de Geomorfología y Cuaternario, No. 1, Actas: 27-28. Santa Rosa. 
in reservoir age (to accommodate local effects of this region), was used in conjunction with this program for calibrating these samples.

The nature of fossil concentration was defined by taphonomic attributes (i.e. preservational features). This kind of study allows death assemblages to be interpreted by observing the shell remains in the context of physical and biological processes. Different attributes (i.e. ratio of opposite valves, fragmentation, surface alteration, bioerosion and shell coloration) were recorded for the main taxa in each sample, and then averaged over the entire sample for comparisons among sites.

Ratio of opposite valves: refers to the number of left and right valves of a particular species in each assemblage. The ratios of left and right valves were pooled for each of the two most common bivalve species (Mytilus chilensis and Tawera gayi). This feature was useful to evaluate transport from the original community.

Fragmentation: is associated to the breakage of the shells. Fragmentation serves as a proxy of environmental energy. The degree of shell fragmentation tends to be highest in environments with high water turbulence and coarse substrates such as beaches and tidal channels as the consequence of impacts with other shells, rocks and waves (Parsons \& Brett 1991), although it can be influenced by ecological interactions, like shell-breaking predation or bioturbation (Zuschin et al. 2003). The degree of fragmentation was estimated following a three-grade scale: whole shell (unbroken), broken shell (broken up to 50\%) and fragment (more than 50\% of the entire shell is absent).

Surface alteration: is generally related to abrasive agents, which produce the loss of surface ornamentation and details of the shell (Parsons \& Brett 1991). It was evaluated as presence or absence.

Bioerosion: refers to the alteration of shells through the activities of organisms, usually in search of either food or shelter, and may take the form of borings, raspings, etching, breakage and abrasion of the shell. It was measured as presence or absence.

Shell coloration: was evaluated as shells that maintain their original color and shells that have lost their color.

Taphonomic categories: To analyze the percentage of fragmentation, surface alteration and bioerosion over the entire sample, four categories were considered: none, when no shell exhibits the attribute considered, low, when the shells that exhibit the attribute represent up to $10 \%$ of the sample; moderate, when the percentage of shells showing the attribute represent between 10 and $50 \%$ of the sample; and high, when this percentage is more than $50 \%$ of the sample.

The ecological characterization of the fossil taxa is based on their living representatives. It includes life habit (mode of life) and feeding-type. These data were used to reconstruct the structure of the mollusk assemblages represented at each individual site.

Mode of life. Considering the life position with respect to the sediment, mollusks were classified as epifauna, when they live on a surface, such as the sea floor, or other organisms; and infauna, when they live in the substrate, especially buried in a soft sea bottom. However, this classification is somewhat arbitrary and artificial because of intergradations between the two categories. In this work, a third intermediate category, semi-infaunal (Stanley 1970), was applied to organisms that live partially buried in the substratum (i.e. Hiatella).

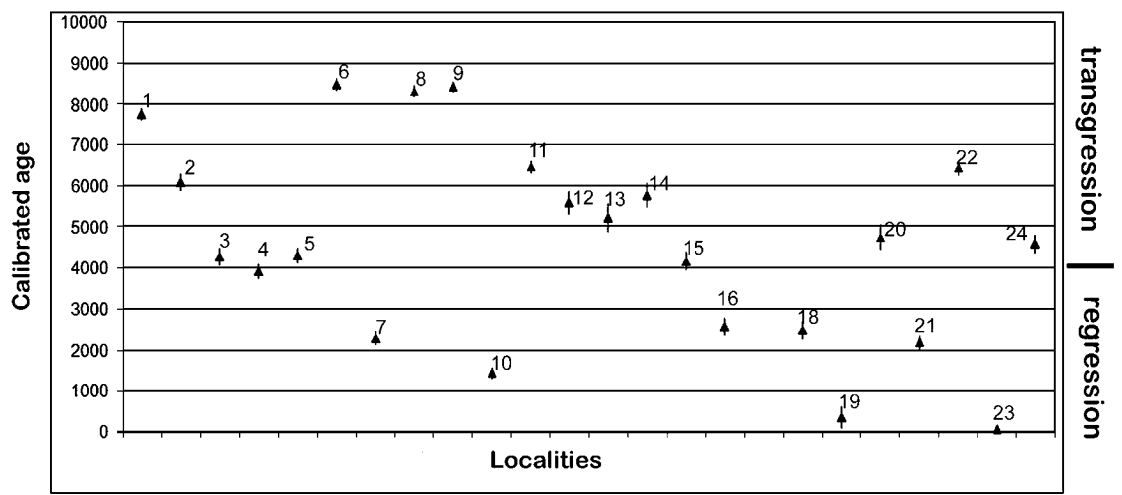

Fig. 2. Graph correlating different Holocene calibrated sites with the Postglacial transgressive/regressive stages. 
Feeding-type. According to their feeding-type, mollusks were described as suspension feeders, deposit feeders, browsers, and carnivores in regard to different feeding habits. Deposit feeders acquire their nutrition from the sediments they inhabit, whereas suspension feeders collect food particles suspended above sediments; browsers encrust vegetation from the surface of substrates where they attach to; and carnivores feed on dead or declining as well as active prey.

Guild structure. After Root (1967), a guild is "a group of species that exploit the same class of environmental resources in a similar way. This term groups together species, without regard to taxonomic position, that overlap significantly in their niche requirements". The purpose of guild analysis is to examine the habitat structure of a community as it functioned in some place at some time. In this study, the species were assigned to guilds by: (1) recognizing the Class to which each species belongs, and (2) identifying the life habit and (3) feeding mode of each species.

Taxonomical diversity. Finally, the presenceabsence (binary) data for each taxa represented in the 3 regions (western, eastern and southern) were set as variables. Analysis of diversity using the PAST program (Hammer et al. 2005) has been made to quantify taxonomical diversity in each region and to identify similarities among them. The statistics apply to association data was the Simpson index, which measures evenness (1-dominance) of the community from 0 to 1 . Results were plotted in a dendrogram.

\section{RESULTS AND DISCUSSION}

\section{a) Chronological control}

Chronological control for the Holocene is based on $24{ }^{14} \mathrm{C}$ calibrated ages (Table 1 ). The ages of the different Pleistocene raised deposits located

TABLE 2. Taxa composition and taxonomic relationships of southern, western and eastern fuegian coast based on Quaternary shared taxa.

\begin{tabular}{|c|c|c|c|c|}
\hline Taxa composition & $\mathrm{N}$ & $\begin{array}{c}\text { Western Sector } \\
\text { (Strait of Magellan) }\end{array}$ & $\begin{array}{l}\text { Southern Sector } \\
\text { (Beagle Channel) }\end{array}$ & $\begin{array}{c}\text { Eastern Sector } \\
\text { (Atlantic Coast) }\end{array}$ \\
\hline \multicolumn{5}{|l|}{ BIVALVIA } \\
\hline Number of Families & 17 & 6 & 16 & 2 \\
\hline Number of Genera & 28 & 11 & 25 & 4 \\
\hline Total Species & 29 & 11 & 26 & 4 \\
\hline \multicolumn{5}{|l|}{ GASTROPODA } \\
\hline Number of Families & 25 & 14 & 20 & 5 \\
\hline Number of Genera & 42 & 22 & 32 & 7 \\
\hline Total Species & 56 & 28 & 39 & 7 \\
\hline \multicolumn{5}{|l|}{ POLYPLACOPHORA } \\
\hline Number of Families & 3 & - & 3 & 1 \\
\hline Number of Genera & 3 & - & 3 & 1 \\
\hline Total Species & 6 & - & 6 & 1 \\
\hline Species in common & 10 & \multirow{2}{*}{\multicolumn{3}{|c|}{$\begin{array}{l}\text { Bivalves: Aulacomya atra, Mytilus chilensis, Brachidontes purpuratus, Mulinia } \\
\text { edulis. } \\
\text { Gastropods: Nacella deaurata, Acanthina monodon, Trophon geversianus, } \\
\text { Xymenopsis muriciformis, Pareuthria plumbea, Siphonaria lessoni. }\end{array}$}} \\
\hline $\begin{array}{l}\text { among } \\
\text { Beagle Channel, } \\
\text { Magellan Strait and } \\
\text { Atlantic fuegian coast }\end{array}$ & & & & \\
\hline Species in common & 11 & \multirow{2}{*}{\multicolumn{3}{|c|}{$\begin{array}{l}\text { Bivalves: Venus antiqua, Retrotapes exalbidus, Tawera gayi, Hiatella solida. } \\
\text { Gastropods: Nacella magellanica, Fissurella picta, Margarella violacea, Crepidula } \\
\text { dilatata, Eumetulla pulla, Adelomelon ancilla, Siphonaria lateralis. }\end{array}$}} \\
\hline $\begin{array}{l}\text { between } \\
\text { Beagle Channel and } \\
\text { Magellan Strait }\end{array}$ & & & & \\
\hline Species in common & 1 & \multirow{2}{*}{\multicolumn{3}{|c|}{ Chitons: Plaxiphora aurata }} \\
\hline $\begin{array}{l}\text { between } \\
\text { Beagle Channel and } \\
\text { Atlantic fuegian coast }\end{array}$ & & & & \\
\hline
\end{tabular}


along the Atlantic fuegian coast are here interpreted on the basis of the U-series analysis obtained by Bujalesky et al. (2001), who relate these outcrops to different oxygen isotopic stages. Unfortunately, geochronological control for the Pleistocene, and particular, for the Holocene of the Magellan Strait research is still incipient in Tierra del Fuego and more work is necessary to confirm these interpretations of different oxygen isotopic stages.

In the meantime, figure 2 correlates the different calibrated localities (most in the Beagle Channel) to the Postglacial marine transgression. Fifteen sites appeared to be related to a transgressive stage which in this region might be took place between ca. 8000 to 4000 years ago, and other eight sites would be related to a posterior regressive stage, after the 4000 yr B.P.

\section{b) Taxa composition and ecological structure}

The faunal composition of Quaternary marine deposits in Tierra del Fuego is summarized in table 2. The species recovered are extant taxa living in the Magellan Region.

The mollusk fauna is diverse. It consists mostly of gastropods (56 species; $61.5 \%$ ), followed by bivalves (29 species; $31.9 \%$ ), and chitons (6 species; $6.6 \%$ ) representing a minor proportion.

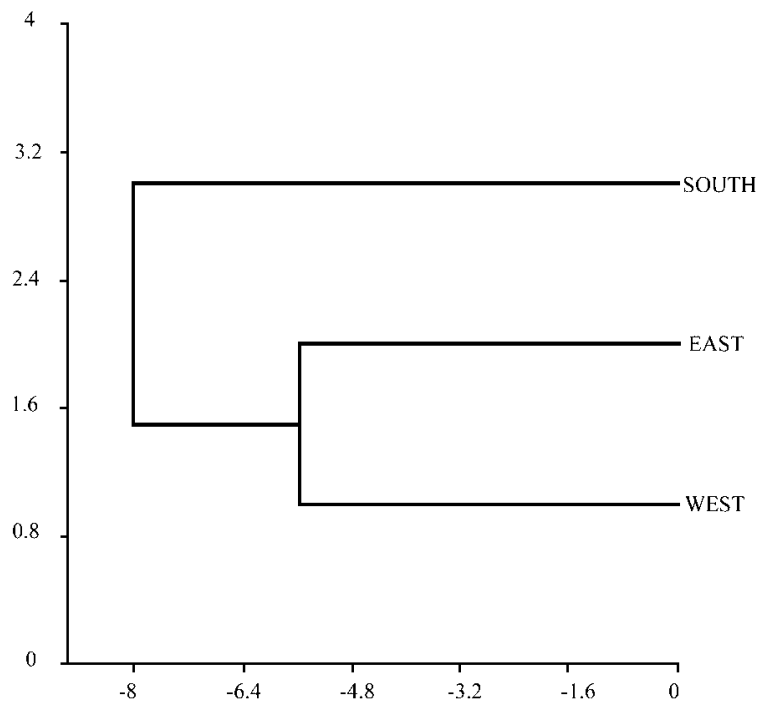

Fig. 3. Dendrogram of the three regions on the basis of their taxa composition (Simpson index) showing the western and eastern sectors of Tierra del Fuego more closely related than the southern region.

Based on taxonomic diversity among regions, The Strait of Magellan is more closely united to the Atlantic fuegian coast than the Beagle Channel, which appeared separately (Fig. 3). These results can be at least partly explained on the basis of a high diversified space in the Beagle Channel.

TABLE 3. Guild structure of the fossil molluscan assemblages.

\begin{tabular}{|c|c|c|c|c|c|c|c|}
\hline \multirow{2}{*}{\multicolumn{2}{|c|}{ Structure of mollusk assemblages }} & \multicolumn{6}{|c|}{ Tierra del Fuego regions } \\
\hline & & \multicolumn{2}{|c|}{ Beagle Channel } & \multicolumn{2}{|c|}{ Magellan Strait } & \multicolumn{2}{|c|}{ Atlantic coast } \\
\hline \multicolumn{2}{|c|}{ Faunal composition } & $\mathrm{SN}$ & RA & $\mathrm{SN}$ & RA & $\mathrm{SN}$ & $\mathrm{RA}$ \\
\hline \multirow{3}{*}{$\begin{array}{l}\text { Group } \\
\text { (class) }\end{array}$} & Bivalves & 26 & $36,6 \%$ & 11 & $27,5 \%$ & 4 & $33,3 \%$ \\
\hline & Gastropods & 39 & $54,9 \%$ & 29 & $72,5 \%$ & 7 & $58,3 \%$ \\
\hline & Quitons & 6 & $8,5 \%$ & - & - & 1 & $8,3 \%$ \\
\hline \multirow[t]{2}{*}{ Life Habit } & Infauna & 17 & $24,3 \%$ & 6 & $15,8 \%$ & 1 & $8,33 \%$ \\
\hline & Epifauna & 53 & $75,7 \%$ & 32 & $84,2 \%$ & 11 & $91,7 \%$ \\
\hline \multirow{4}{*}{$\begin{array}{l}\text { Feeding } \\
\text { Mode }\end{array}$} & Suspension & 24 & $33,8 \%$ & 14 & $35 \%$ & 4 & $33,3 \%$ \\
\hline & Deposit & 4 & $5,6 \%$ & - & - & - & - \\
\hline & Carnivore & 21 & $29,6 \%$ & 9 & $22,5 \%$ & 5 & $41,6 \%$ \\
\hline & Browser & 22 & $31 \%$ & 17 & $42,5 \%$ & 3 & $25 \%$ \\
\hline Guilds & & \multicolumn{6}{|c|}{$\begin{array}{l}\text { Suspension epifaunal bivalves }(11 \%) \\
\text { Suspension infaunal bivalves }(15,3 \%) \\
\text { Suspension semi-infaunal bivalve }(1,1 \%) \\
\text { Deposit infaunal bivalves }(4,4 \%) \\
\text { Suspension epifaunal gastropods }(4,4 \%) \\
\text { Browser gastropods }(28,6 \%) \\
\text { Browser chitons }(6,6 \%) \\
\text { Carnivores }(28,6 \%)\end{array}$} \\
\hline
\end{tabular}

SN: Species Number; RN: Relative Abundance 
Guild structure based on faunal composition, life habit and feeding mode is given in table 3. Mollusks are represented by organisms with different life habit and feeding types. In the 3 regions considered, the epifauna dominated over the infauna, and suspension feeders and browsers are better represented than carnivores, with deposit feeders in a low proportion.

\section{c) Taphonomy}

Most of the mollusk assemblages occurring in these deposits preserve a mixture of non-contemporaneous remains and, thus, are time-averaged. The co-ocurrence of taxa associated to different substrates, shows that these shell beds can be regarded as a mixture of mollusks originally inhabiting several local habitats and different local paleocommunities, which suffered post-mortem modification (i.e., a certain degree of both horizontal and vertical displacement) before final burial. These assemblages correlate with the "multi-habitat time-averaged assemblage" of Kidwell \& Bosence (1991).

Taphonomic differences among regions are related to different energies and periods of exposure within each environment (Table 4). Some groups (i.e. mytilids) show a higher degree of breakage and fragmentation than other groups (i.e. venerids).
The ratio of opposite valves is always unequal in the Magellan Strait and the Atlantic coast, indicating major transportation than the Beagle Channel, where some localities gave the same ratio of opposite valves. Shell fragmentation was moderate to high in the Magellan Strait and the Atlantic Ocean, but varied from none to high in the Beagle Channel, suggesting different energies and periods of exposure. Shell surface of alteration was higher in the Magellan Strait which can be related with major periods of exposure within a high energy environment. These shells are abraded and exhibit rounded edges. In relation to bioerosion, Mytilus shells did not exhibit signs of bioerosion, and a low proportion of eroded shells correspond to holes produced by drilling gastropods. However, a major proportion of Tawera shells exhibit holes produced by these predators. Finally, analysis of shell coloration showed that Mytilus shells maintain the original color, or suffered partial color degradation, but Tawera shells exhibit a partial to total degradation of the original color. The timing of color decay probably varied in response to taphonomic conditions. This assumption is based on the fact that exposure to both light and oxygen strongly degrades pigments, producing decay and loss of color, while a rapid burial may retard the processes of degradation (Curry 1999). After this analysis, differences and/or

TABLE 4. Taphonomic attributes of selected species at localities in southern (Beagle Channel), western (Strait of Magellan) and eastern (Atlantic coast) Tierra del Fuego.

\begin{tabular}{|c|c|c|c|}
\hline \multirow{2}{*}{ Taphonomic attributes } & \multicolumn{3}{|c|}{ Regions in Tierra del Fuego } \\
\hline & Beagle Channel & Strait of Magellan & Atlantic coast \\
\hline \multicolumn{4}{|l|}{ Mytilus chilensis } \\
\hline Ratio of opposite valves & $\begin{array}{l}\mathrm{n}_{\mathrm{rv}} \neq \mathrm{n}_{\mathrm{lv}} \\
\mathrm{n}_{\mathrm{rv}=\mathrm{n}_{\mathrm{lv}}}\end{array}$ & $\mathrm{n}_{\mathrm{rv}} \neq \mathrm{n}_{\mathrm{lv}}$ & $\mathrm{n}_{\mathrm{rv}} \neq \mathrm{n}_{\mathrm{lv}}$ \\
\hline Fragmentation & None to High & Moderate to High & Moderate to High \\
\hline Surface alteration & None to Moderate & None to High & Low to Moderate \\
\hline Bioerosion & None to Scarce & None to Scarce & None \\
\hline Shell color & Original or Discoloration & & Original or Discoloration \\
\hline \multicolumn{4}{|l|}{ Tawera gayi } \\
\hline Ratio of opposite valves & $\begin{array}{l}\mathrm{n}_{\mathrm{rv}} \neq \mathrm{n}_{\mathrm{lv}} \\
\mathrm{n}_{\mathrm{rv}=} \mathrm{n}_{\mathrm{lv}}\end{array}$ & $\mathrm{n}_{\mathrm{rv}} \neq \mathrm{n}_{\mathrm{lv}}$ & - \\
\hline Fragmentation & Low to High & Moderate to High & - \\
\hline Surface alteration & None to Moderate & High & - \\
\hline Bioerosion & None to High & Scarce to High & - \\
\hline Shell color & Discoloration & Discoloration & - \\
\hline
\end{tabular}

Source: Gordillo, 1992; Gordillo \& Isla, 2008; Cárdenas \& Gordillo, 2009; Cárdenas (pers. com.). 
similarities among regions can be partly explained by taphonomic reasons associated to each dead assemblage at the different sites.

\section{d) Paleoecology}

Quaternary mollusk assemblages from Tierra del Fuego represent typical shallow benthic paleocommunities which developed during different stages within this period, and variations in faunal composition would mainly be related to differences in substratum types, water depth and sedimentation rates.

Pleistocene assemblages were only preserved along the Atlantic coast. They are mostly composed of infaunal bivalves (Gordillo 2006), and exhibit lower diversity than the Holocene ones (Gordillo \& Isla 20083).

Holocene assemblages from southern Tierra del Fuego coast are more diverse than the Holocene assemblages from the Magellan Strait, and these ones are more diverse than their equivalents from the Atlantic coast. It would reflect a more diversified space or heterogeneous ecosystem in the Beagle Channel, with a large variety of habitats, with differences within short distances, in coincidence with what was also observed in living communities in the region (Antezana 1999). As it happens today in southern Tierra del Fuego, the development of different local paleocommunities appears to be associated with a complex mosaic of microhabitats, and the presence of hard (e.g. rocky intertidal) and soft areas (e.g. sandy beaches), which are common features on the Beagle Channel seafloor.

When comparing the mollusk associations recovered from older marine layers (Early Holocene) and younger ones (Middle to Late Holocene), an increasing number of taxa in the last ones is clearly evidenced (see Gordillo et al. 2005, Rabassa et al. 2009²). After deglaciation, the first appearance of two plastic taxa (Mulinia edulis and Mytilus chilensis) is followed by the early additions of few other species (Aulacomya atra and Yoldia woodwardii). These taxa are typical of tidal flats, and areas more exposed to highly unstable conditions with longer episodes of exposure. In southern Chile, Velasco \& Navarro (2003) demostrated that Mytilus chilensis and Mulinia edulis exhibit a high degree of physiological plasticity. Reid \& Osorio (2000) also mentioned a group of euryhaline taxa (including Mytilus chilensis, Aulacomya atra and Mulinia edulis) that tolerate sharp salinity gradients along a fjord system in southern Chile. Thus, organisms which represent the oldest marine stages during the Holocene tolerate large fluctuations in quality and quantity of suspended particulate matter due mainly to the resuspension of benthic sediment by the action of winds and tides.

Then, a phase of major expansion of the fauna with further diversification of taxa indicates an evolution towards modern conditions. These changes in faunal composition from a low diverse to a more diverse fauna are related to local changes associated to initial incoming of freshwater and the progressively input of marine waters (Gordillo et al. 2005). They represent an ecosystem transition which started with vacant niches first occupied by opportunistic species, and/or eurithopic taxa, and subsequent replacement by more diverse taxa, associated to the proliferation of habitats occurred under truly marine conditions during the Holocene.

\section{CONCLUSIONS}

Quaternary time-averaged mollusk assemblages from Tierra del Fuego provides a very good picture of the overall coastal benthic biodiversity patterns in the region. The composition of mollusk species showed remarkable similarities with present-day fauna, which reinforces the hypothesis that climatic conditions have maintained without significant changes since at least the Middle Pleistocene. However, taphonomic and paleoecological analysis of shell assemblages shows the existence of different shallow benthic communities, which represent spatial and temporal variations among regions and sites.

\section{GAPS AND PERSPECTIVES}

Paleoenvironmental studies on Quaternary marine environments of the mainland of Tierra del Fuego have been undertaken along the northern coast of the Beagle Channel and along the western coast of the Magellan Strait over the last years. However, there are still some Magellan regions where little or no systematic study has been undertaken, such as other islands of the Magellan Archipelago. Thus, much more research is needed 
in this region to obtain information relating to paleoecology of mollusk associations throughout the Quaternary period.

\section{ACKNOWLEDGEMENTS}

Research on Quaternary mollusks from Tierra del Fuego was financed by CONICET projects (PEI04-6131, PIP-05-6323, PIP-09-260). This work is a contribution to the ANPCyT-PICT-06-00468 project of the National Agency for the Promotion of Science and Technology. The author wishes to thank Jorge O. Rabassa, Andrea Coronato, Graciela Alsina, Sandra Amuchástegui, Daniel Aureliano, Javiera Cárdenas, Carlos Ferrer and Carlos Gómez who shared field and/or laboratory work.

\section{LITERATURE CITED}

Aitken, A. E. 1990. Fossilization potential of Arctic fjord and continental shelf benthic macrofaunas. In Dowdeswell, J.A. \& J.D. Scourse, eds., Glacimarine Environments: Processes and Sediments. Geological Society of London Special Publication 53: 155-176

Alberó, M.C., F. Angiolini \& E. Piana 1987. Holocene 14-C reservoir effect at Beagle Channel (Tierra del Fuego, Argentina Republic). Quaternary of South America and Antarctic Peninsula 5: 59-71.

Angiolini, F.E. \& J. Fernández 1984. Datación C-14 de valvas de Mytilus, desecho de alimentación proveniente de Nombre de Jesús. El "efecto reservorio" una posible explicación para su edad discrepante. Seminario sobre la situación de la investigación de las culturas indígenas de la Patagonia. Biblioteca del 5to Centenario del Descubrimiento de América, Madrid: 101-105.

Antezana, T. 1999. Plankton of southern Chilean fjords: trends and linkages. Scientia Marina 63 (Supl.): 69-80.

Brambati, A., S. De Muro \& A. Di Grande 1998. Marine transition Holocene terraces in the Eastern area of the Straits of Magellan, Chile. Bollettino Di Geofisica Teorica ed Applicata 39: 47-76.

Bujalesky G., S. Alliota \& F. Isla 2004. Facies del subfondo del canal Beagle, Tierra del Fuego.
Revista de la Asociación Geológica Argentina 59: 29-37.

Bujalesky, G.G., A.M. Coronato \& F. Isla 2001. Ambientes glacifluviales y litorales cuaternarios de la región del río Chico, Tierra del Fuego, Argentina. Revista de la Asociación Geológica Argentina 56: 73-90.

Candel, M.S., A.M. Borromei, M.A. Martínez, S. Gordillo, M. Quattrocchio \& J. Rabassa 2009. Middle-Late Holocene palynology and marine mollusks from Archipelago Cormoranes area, Beagle Channel, southern Tierra del Fuego, Argentina. Palaeogeography, Palaeoclimatology, Palaeoecology 273: 111-122.

Cárdenas J. \& S. Gordillo 2009. Late Quaternary molluscan assemblages from Tierra del Fuego (southern South America): a taphonomic analysis. Andean Geology 36: 81-93.

Curry, G.B. 1999. Original shell colouration in Late Pleistocene terebratulid brachiopods from New Zealand. Palaeontologia Electronica 2: 2.

Feruglio, E. 1950. Descripción Geológica de La Patagonia. Dirección General de Y.P.F., Buenos Aires, vol. 3, $431 \mathrm{pp}$.

Gordillo, S. 1991. Paleoecología de moluscos marinos del Holoceno Medio en Isla Gable, Canal Beagle (Tierra del Fuego, Argentina). Ameghiniana 28: 127-133.

Gordillo, S. 1999. Holocene molluscan assemblages in the Magellan region. Scientia Marina 63 (Supl. 1): 15-22.

Gordillo, S. 2006. Pleistocene Retrotapes del Río, 1997 (Veneridae, Bivalvia) from Tierra del Fuego, Argentina. Ameghiniana 43: 757-761. Gordillo, S., G.G. Bujalesky, P.A. Pirazzoli, J.O. Rabassa \& J-F. Saliege 1992. Holocene raised beaches along northern coast of the Beagle Channel, Tierra del Fuego, Argentina. Palaeogeography, Palaeoclimatology, Palaeoecology 99: 41-54.

Gordillo, S., A. Coronato \& J. Rabassa 1993. Late Quaternary evolution of a subantarctic paleofjord, Tierra del Fuego. Quaternary Science Reviews 12: 889-897.

Gordillo, S., A. Coronato \& J. Rabassa 2005. Quaternary molluscan faunas from the island of Tierra del Fuego after the Last Glacial Maximum. Scientia Marina 69: 337-348. 
Gordillo, S., J. Rabassa \& A. Coronato 2008. Paleoecology and paleobiogeographic patterns of Mid-Holocene mollusks from the Beagle Channel (southern Tierra del Fuego, Argentina). Revista Geológica de Chile 35 (2): 1-13.

Halle, T. G. 1910. On Quaternary deposits and changes of sea level in Patagonia and Tierra del Fuego. Bulletin of the Geological Institution of the University of Upsala 9: 93-117.

Hammer, Ø., Harper, D.A.T. \& P.D. Ryan 2005. PAST-PAlaeontological Statistics, ver. 1.35. In: http://folk.uio.no/ohammer/past

Isla, F.I. \& G.G. Bujalesky 2000. Cannibalisation of Holocene gravel beach-ridge plains, northern Tierra del Fuego, Argentina. Marine Geology 170: 105-122.

Kidwell, S. M. 2001. Preservation of species abundance in marine death assemblages. Science 294: 1091-1094.

Kidwell, S. M. 2002. Time-averaged molluscan death assemblages: palimpsests of richness, snapshots of abundance. Geology 30: 803-806.

Kidwell, S. M. \& D.W.J. Bosence 1991. Taphonomy and time averaging of marine shelly faunas. In Allison, P. A. \& D.E.G Briggs (eds.): Taphonomy: releasing the data locked in the fossil record, 211-290. Plenum, New York.

Parsons, K. M. \& C.E. Brett 1991. Taphonomic processes and biases in modern marine environments: an actualistic perspective on fossil assemblage preservation. pp. 22-65. In Donovan, S. K., 1991. The Processes of Fossilization. Belhaven Press, London.

Porter, S., C.J. Heusser \& C. Stuiver 1984. Holocene sea-level change along the Strait of Magellan and Beagle Channel, southernmost America. Quaternary Research 22: 59-67.

Rabassa, J., C.J. Heusser \& R. Stuckenrath 1986. New data on Holocene sea transgression in the Beagle Channel: Tierra del Fuego, Argentina. Quaternary of South America and Antarctic Península 4: 291-309.
Rabassa, J., A. Coronato, G. Bujalesky, M. Salemme, C. Roig, A. Meglioli, C. Heusser, S. Gordillo, F. Roig, A. Borromei \& M. Quattrocchio 2000. Quaternary of Tierra del Fuego, southernmost South America: an updated review. Quaternary International 68-71: 217-240.

Rabassa, J., S. Gordillo, C. Ocampo \& P. Rivas Hurtado 2008. The southernmost evidence for an interglacial transgression (Sangamon?) in South America. First record of upraised Pleistocene marine deposits in Isla Navarino (Beagle Channel, Southern Chile). Geologica Acta 6: 251-258.

Reid, D.G. \& C. Osorio 2000. The shallow-water marine Mollusca of the Estero Elefantes and Laguna San Rafael, southern Chile. Bulletin of the Natural History Museum, London (Zoology) 66: 109-146.

Reimer, P. \& R. Reimer 2000. Marine reservoir correction database http://calib.org/marine.

Root, R. B. 1967. The niche exploitation pattern of the blue-gray gnatcatcher. Ecological Monographs 37: 317-350.

Schellmann, G. \& U. Radtke 2003. Coastal terraces and Holocene sea-level changes along the Patagonian Atlantic coast. Journal of Coastal Research 19: 983-996.

Stanley, S. M. 1970. Relation of shell form to life habits of the Bivalvia (Mollusca). Boulder, The Geological Society of America, Inc.

Stuiver, M. \& P.J. Reimer 1993. Extended 14C database and revised Calib radiocarbon calibration program. Radiocarbon 35: 215-230.

Velasco, L.A. \& J.M. Navarro 2003. Energetic balance of infaunal (Mulinia edulis King, 1831) and epifaunal (Mytilus chilensis Hupé, 1854) bivalve in response to wide variations in concentration and quality seston. Journal of Experimental Marine Biology and Ecology 296: 79-92.

Zuschin, M., M. Stachowitsch \& R.J Jr. Stanton 2003. Patterns and processes of shell fragmentation in modern and ancient marine environments. Earth Science Reviews 63: 33-82. 